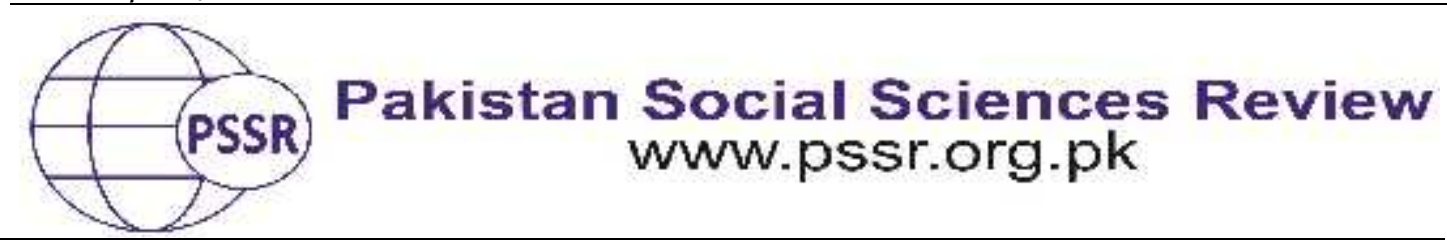

RESEARCH PAPER

\title{
Convergence in Human Development across Districts of Pakistan: Evidence from Club Convergence Test
}

\author{
Noor Ahmed ${ }^{*}$ Babar Hussain ${ }^{2}$ Arshad Ali Bhatti ${ }^{3}$
}

1. Ph D Scholar, School of Economics, IIIE, International Islamic University Islamabad, Pakistan

2. Assistant Professor, School of Economics, IIIE, International Islamic University Islamabad, Pakistan

3. Assistant Professor, School of Economics, IIIE, International Islamic University Islamabad, Pakistan

\begin{tabular}{|c|c|}
\hline PAPER INFO & ABSTRACT \\
\hline $\begin{array}{l}\text { Received: } \\
\text { February 28, } 2021 \\
\text { Accepted: } \\
\text { June } 25,2021 \\
\text { Online: } \\
\text { June } 30,2021\end{array}$ & $\begin{array}{l}\text { Studies on the convergence club have become a focal point in } \\
\text { economic growth and development literature over the last three } \\
\text { decades. This paper analyzes the club convergence hypothesis } \\
\text { going beyond the traditional use of GDP per capita. It examines } \\
\text { the convergence club of } 97 \text { Pakistani districts over the period }\end{array}$ \\
\hline $\begin{array}{l}\text { Club } \\
\text { Convergence, } \\
\text { Human } \\
\text { Development, } \\
\text { PCA }\end{array}$ & $\begin{array}{l}\text { measuring development through convergence and the } \\
\text { clustering method of Phillips and Sul (2007). The index consists } \\
\text { of } 3 \text { sub-indices of education, health, and household welfare } \\
\text { level, with each index further composed of } 5 \text { indicators. The }\end{array}$ \\
\hline $\begin{array}{l}\text { *Corresponding } \\
\text { Author }\end{array}$ & $\begin{array}{l}\text { indicators to get sub-indices and a final development index. } \\
\text { Results of the study indicate that the districts do not converge to } \\
\text { the same long-run equilibrium. Instead of overall convergence, } \\
\text { we find eleven convergence clubs and one non-convergent } \\
\text { group for human development. The existence of clubs means } \\
\text { that measures aimed at reducing disparities in human } \\
\text { development and promoting regional growth should consider } \\
\text { the specific characteristics revealed in the convergence analyses. } \\
\text { Spatial differences thus need to be addressed mainly through } \\
\text { pro-poor regional policies. }\end{array}$ \\
\hline
\end{tabular}

\section{Introduction}

The "convergence" debate is a hot topic in literature. The basis of the convergence proposition was first presented in the writings of Tucker and Hume in the mid-18 th century (Elmslie, 1995). However, the convergence-divergence discussion itself is deemed to have been founded by Veblen's (1915) claim that the benefit in development lies with latecomers because the early developing nations make the initial errors and construct the technology. Most researchers in the modern 
growth debate after World War II have concentrated on the neoclassical model of growth originating from Solow in 1956. Solow modifies the Harrod-Domar modelby adding up labor as a factor of production, consequently completing the equation of growth. Solow also argues that countries with a higher capital stock per capita have a lower rate of return on capital. Therefore, because of arbitrage, capital will flow to the poorer nations from the rich. This accumulation of capital will help the countries to converge. In accordance with Solow (1956), advocates of the neoclassical pattern conclude that inequalities are bound to lessen with growth (Sala-I-Martin and Barro, 1995).

The fall-down of the neo-classical model in explaining steady-state growth leads to a new type of model known as endogenous models of growth (Romer, 1986; Lucas, 1988). These models are based on processes such as inter-temporal knowledge spillovers and "learning by doing," averting returns to scale from declining. Contrary to the neoclassical model, the theories of endogenous growth (Romer, 1986; Lucas, 1988; Aghionn and Howit, 1998), institutional theory (Lundvall, 1992; Nelson, 1993) and the new economic geography (Krugman, 1991; Venables, 1999) tend to agree with the fundamental statement of Myrdal (1957) that growth is a growing spatial practice that results in higher disparities.

One type of growth theory (Azariadis \& Drazen, 1990; Barro \& Sala-iMartin,1992; Chatterji,1992; David,1994; Durlauf\& Johnson,1995; Quah,1996; Azariadis,1996; Galor,1996) shows that economies that are rather similar in their structural characteristics (e.g., production technology, preferences, government policies, etc.) may, however, converge to different steady-state equilibria if they differ in terms of initial conditions. Hence, within a group of similar economies, a common balanced growth path can only be expected if their initial conditions are also identical. So, economies that approach the same steady-state equilibrium are said to form a convergence club (Galor, 1996). The notion of convergence clubs was first defined at the end of the eighties by Baumol and Wolff (1988). Chatterji (1992) describes that a convergence club implies various regions forced in the long run to a steady-state level with identical income per capita. At a country level, Quah introduced the notion of the club convergence hypothesis in 1996. He established a method (not based on a theoretical model) designed for modelling the dynamics of cross-sectional distributions of economies. Quah (1996) described that the per capita income developed into a twin peaks distribution at the world level so that there is no convergence process among economies.

Despite the rich literature on regional convergence worldwide, the club convergence at the district level in Pakistan has been almost entirely neglected. In this perspective, this study empirically analyzes the issue of different districts converging to several steady states across Pakistan and the manifestation of "convergence clubs" as was proposed by various scholars in the growth literature (see Baumol, 1986; Durlauf, 1995; and Galor, 1996). 


\section{Literature Review}

Empirical studies on the convergence club hypothesis have reached various outcomes concerning the quantity and features of groups, particularly influenced deeply by the methods employed. The empirical methods are oriented on the following directions: chronological series tests of unit root and co-integration (Evans \& Karras, 1996; Evans, 1998; Kutan \& Yigit, 2005; Guetat \& Serranito, 2007; Siklos, 2010; Lopez \& Papell, 2012) and cross-section augmented Solow regression (Barro \& Sala-i-Martin, 1992). While Phillips and Sul (2007) proposed a non-linear factor model based on a panel convergence, the convergence clubs being identified within the panels using a clustering procedure.

By using a simple non-linear model, Wolff and Baumol (1988) concluded the existence of two clubs: a high income convergence club and a low income nonconvergent one. Linking the economic gap at some time with the particular economic gap at a previous time and incorporating more influences of those former levels, Chatterji (1992) establishes a two clubs convergence that are mutually exclusive: one comprising the rich nations and another consisting of the poor ones. By employing regression tree analysis, Quah (1993) examines the club convergence hypothesis for 105 countries over a period of 1960-1990 using per capita income as a measure of development. Quah observed a growing twin peak involving the division of regions into two dissimilar income groups. Using a regression tree analysis, Durlauf and Johnson (1995) found evidence for club convergence to multiple steady states for 121 countries. Their results suggest that heterogeneity in the available level of human capital and its growth determines the formation of clubs. Adding to this concept that there can be multiple steady-state equilibria, Galor (1996) developed models for club convergence. Where, he argued that, in the long run, countries with similar characteristics do tend towards common steady-state equilibrium, but there is no convergence across different sets of equilibria.

While the studies mentioned above focused on the club convergence phenomena are based on the methods that could not address the issue of individual heterogeneity, economic structure, economic transition and convergence path. However, Phillips and Sul (2007) came up with a new technique to cluster panels into club convergence groups. Phillips and Sul argued about the role of heterogeneity over time and across economies in the transitional dynamic of economic growth. Subsequently, there has been a proliferation of work on economic convergence after Phillips and Sul (2007). Some of these studies are discussed below. Aksoy et al. (2019) investigated club convergence in per capita income across 81 NUTS-III regions in Turkey for the period 1987-2017. Their result showed strong evidence of convergence clubs across Turkish regions. For the period 1987-2001, they found five clubs and six clubs in the second period covering 2004-2017.

Tian et al. (2016) examined regional income convergence in China for 31 provinces over the period 1978-2013. They identified two convergence clubs and suggested that investment, human capital, and openness increase the probability of 
regions in the high income club. A similar study was conducted by Li et al. (2018), considering 2286 regions of China for the period 1992-2010. Their result shows six convergence clubs and concludes that per capita fixed assets, population density, and industrialization have promoted convergence club formation.

Velázquez et al. (2015) analyze the convergence patterns in income per capita across the Mexican states over the period 1940-2015 by applying a time-series approach considering temporal and transitional heterogeneity. Results indicate that Mexican states do not converge to the same long-run equilibrium. Instead of overall convergence, club convergence was found for both regional inequality and income per capita. Bartkowska and Riedl (2009) investigate convergence clubs' formation in per capita income among 206 European regions from 1990 to 2005. They find that convergence clubs exist, indicating that European regions form five separate groups converging to their steady-state paths. Hao (2008) evaluated the convergence club using China's provincial data over the period 1985-2000. His study found that the Chinese regions are clustered into two groups where these two convergence clubs exhibit heterogeneity among growth behaviors.

The above literature showed that extensive research on club convergence is confined to the use of GDP per capita. Recently the concept of club convergence has extended to the development index for convergence across countries/regions. Some of the studies are discussed below.

Basel et al. (2020) analyze the convergence club based on the augmented index for measuring development across 102 economies. The index is composed of seven major development indicators: education, health, energy use, access to water and sanitation, environment, living standard, and good governance. The study examines the club formation of 102 economies over a period o 1996-2015 and reveals four final convergence clubs.

Montan e's et al. (2018) analyses the convergence hypothesis for Spain based on the income and human development index over the periods 1980-2007 and 19802014. They find that the number of clubs decreases for the period 1980-2014, indicating that the Great Recession lowered the provincial disparities. Szendi (2014) analyzes the Human Development Indicator (HDI) in the countries of the world from 1990 to 2010 to analyze the development from an economic and social aspect, using beta convergence of HDI and its club-convergence. The results describe small economic and social convergence. The convergence clubs also support the prevailing tendencies of the world in the aspect of regional differences and the global centreperiphery theory.

The review of the literature clearly shows that for Pakistan, no studies have been conducted to understand the convergence club hypothesis at the district level, taking into consideration the broader aspects of development. Thus, we construct an augmented development index that could capture the comprehensive aspects of development into some measurable units and then understand the club convergence hypothesis on the basis of this index. 


\section{Material and Methods}

\section{Variables Description and Data Source}

Several economists criticize the use of per capita GDP as a measure of development as it fails to account for the wider aspect of human well-being, which is far beyond what growth rates in income can capture (Sen, 1983; Goossens, 2007; Stiglitz et al., 2009; Todaro \& Smith, 2011; Schepelmann et al., 2010). In recent growth literature, renowned economist Xavier Sala-I Martin has suggested that convergence can be applied in human development (Roy \& Bhattacharjee, 2009). So, in this study, we attempt to analyse the convergence club for 97 districts based on an augmented index for measuring development over a period of 2004-2015.

The development index is composed of three sub-indices of education, health and Household living standard. Each of the sub-indices is based on five indicators. The indicators are aggregated through weights obtained from Principal Component Analysis (PCA) (Basel et al., 2020). Data for these indicators at the district level is collected from six PSLM Surveys. The list of indicators used to compute sub-indices is given in Table 1.

\section{Table 1}

List of indicators of education, health and household welfare level

\begin{tabular}{|c|c|c|c|}
\hline \multirow[b]{2}{*}{$\begin{array}{l}\mathbf{N} \\
\mathbf{0}\end{array}$} & \multicolumn{3}{|c|}{ Development Index } \\
\hline & Education Index & Health Index & Household welfare Index \\
\hline 1 & $\begin{array}{l}\text { Population that has } \\
\text { attended school ever }\end{array}$ & $\begin{array}{l}\text { Children that have been } \\
\text { immunized (Treatment of } \\
\text { diarrhea in children (Aged } \\
\text { under 5) }\end{array}$ & Households with electricity \\
\hline 2 & $\begin{array}{c}\text { Population that has } \\
\text { completed primary level } \\
\text { or higher }\end{array}$ & $\begin{array}{c}\text { Children aged 12-23 } \\
\text { months) } \\
\text { Children affected by } \\
\text { diarrhea in last } 30 \text { days } \\
\text { (Aged under 5) }\end{array}$ & Household with Gas. \\
\hline 3 & $\begin{array}{l}\text { Net enrolment rate at the } \\
\text { middle level } \\
\text { (age 11-13) }\end{array}$ & $\begin{array}{l}\text { Treatment of diarrhea in } \\
\text { children (Aged under }\end{array}$ & $\begin{array}{c}\text { Households by housing } \\
\text { ownership. }\end{array}$ \\
\hline 4 & $\begin{array}{c}\text { Net enrolment rate at the } \\
\text { Matric level } \\
\text { (age 14-15) }\end{array}$ & Pre-natal consultations & $\begin{array}{c}\text { Households with RCC } \\
\text { Roof. }\end{array}$ \\
\hline 5 & $\begin{array}{l}\text { Adult Literacy level (15 } \\
\text { years and older } \\
\text { population) }\end{array}$ & $\begin{array}{l}\text { Health Consultation } \\
\text { (Number of individuals } \\
\text { who consulted for treatment } \\
\text { expressed as proportion of } \\
\text { total individuals fallen sick } \\
\text { during last two weeks) }\end{array}$ & $\begin{array}{l}\text { Households with flush } \\
\text { toilet. }\end{array}$ \\
\hline
\end{tabular}




\section{Data Limitation}

Data for the study is taken from six PSLM Surveys over the period 2004-2015. PSLM surveys cover data for 116 districts across four provinces of Pakistan. For this study, 19 districts are dropped from the data due to missing observations. The detail of the districts dropped is given in Table 2.

Table 2

List of districts dropped from data due to missing observation

\begin{tabular}{|c|c|c|c|c|}
\hline & \multicolumn{4}{|c|}{ Provinces } \\
\hline & Punjab & Sindh & $\mathbf{K P}$ & Balochistan \\
\hline Districts & $\begin{array}{l}\text { Chinio, } \\
\text { Nankana } \\
\text { Sahib }\end{array}$ & $\begin{array}{c}\text { Kashmore, Shahdadkot, } \\
\text { Tando Allah Yar, Tando } \\
\text { Muhammad Khan, } \\
\text { Sujawal, Umerkot, } \\
\text { Matiari, Jamshoro }\end{array}$ & Tor Ghar & $\begin{array}{l}\text { Ketch, Panjgur, Kohlu, } \\
\text { Derabugti, Sheerani, } \\
\text { Washuk, Nushki, harnai }\end{array}$ \\
\hline
\end{tabular}

\section{Selection of Model}

This study utilizes the log t-test suggested by Sul and Phillips (2007) to study the convergence of development index across districts of Pakistan. The technique is empirically sound as it endogenously classifies regions with similar characteristics into unique groups called clubs. The importance of the logt-test is that the test employed in this technique doesn't depend on any assumption relating to trend or stochastic non-stationarity of the variable of concern and the common factors in the panel across individuals (Aksoy et al. 2019).

\section{The $\log$ t-test}

The methodology is dependent on a pioneering disintegration of the variable of concern. Panel data are generally decomposed in the following manner:

$$
\log y_{i t}=\varphi_{i} u_{t+} \varepsilon_{i t}
$$

Where $u_{t}$ signifies the common factor, $\varphi_{i}$ symbolizes the component of unit characteristic, and $\varepsilon_{i t}$ represents the error term. On the other side, in the pattern applied here, the log of income per capita, $\log y_{i t}$ has a time-varying factor depiction that might be resulting from the representation of typical panel data:

$$
\log y_{i t}=\left(\varphi_{i}+\varepsilon_{i} \downarrow u_{t}\right) u_{t=} \delta_{i t} u_{t}
$$

where $\boldsymbol{\delta}_{i t}$ absorbs the error term and hence the unit-specific factor signifying the distinctive fraction that differs over time. The first model tried to reveal the behavior of the individual $\log y_{i t}$ by the common factor $\mu_{t}$ and two-unit characteristic components $\varphi_{i}$ and $\varepsilon_{i t}$. The second method looks to explain per capita income by calculating the share $\left(\delta_{i t}\right)$ of the common growth path $\left(\boldsymbol{u}_{t}\right)$ that country $i$ undertakes. To model the transition coefficients $\boldsymbol{\delta}_{i t}$, a relative transition coefficient $\boldsymbol{h}_{i t}$ is built: 


$$
h_{i t}=\log y_{i} / N^{-1} \sum_{i}{ }^{N}=1 \log y_{i t}=\sigma_{i t /} N^{-1} \sum_{i}{ }^{N}=\sigma_{i t}
$$

$h_{i t}$ stand for the transition path of economy $i$ relative to the cross-section average and has a dual understanding: first, it determines the behavior of individual regions in relation to other regions, and second, it portrays the relative disappearance of region $I$ from the common growth path $\mu_{\mathrm{t}}$. In the case of convergence, when all regions move in the direction of the identical transition path, $h_{i t} \rightarrow 1$ for all $i$ as $t \rightarrow \infty$. Afterwards, the cross-sectional variance of $h_{i t}$, indicated by $V^{2}{ }_{t}$ $=N^{-1} \sum_{i}\left(h_{i t}-1\right)^{2}$, converges to zero. There are various possible conclusions in the case of no convergence. For example, $V_{t}$ might converge to a positive number, an attribute of convergence club, or remain restricted above zero and not converge or diverge.

In order to discover the null hypothesis, Sul and Phillips (2007) model $\delta_{\text {it }}$ in a semi-parametric form:

$$
\delta_{i}=\delta_{i}+\sigma_{i} \mathcal{S}_{i t / L(t) t^{a}}
$$

Where $\delta_{i}$ is fixed, $\sigma_{i}$ is an idiosyncratic scale parameter, $\xi_{i t}$ is $\operatorname{iid}(0,1), L(t)$ is a function varying slowly (such that $\mathrm{L}(\mathrm{t}) \rightarrow \infty$ as $\mathrm{t} \rightarrow \infty$ ) and $\alpha$ is the decay rate.

The null hypothesis of convergence can be described as:

$$
H_{0}: \delta_{i}=\delta \text { and } a \geq 0
$$

It is tested against the alternative $H_{A}: \delta_{i} \neq \delta$ for all $i$ or $\boldsymbol{a}<0$. Remember that different transitional models of regions $i$ and $j$ are apparent under the null hypothesis of convergence, including momentary divergence, which refers to periods where $\delta_{i} \neq \delta_{j}$. Consequently, the technique suggested by Sul and Phillips (2007)allows us to identify convergence even in the case of transitional divergence, where other techniques such as stationarity tests (Franses and Hobijn, 2000) fail. Principally, stationary time series techniques are incapable to discover the asymptotic co-movement of two-time series, and consequently, the convergence proposition is rejected mistakenly.

Considering Eq. (4), Sul and Phillips (2007) explain that the cross-sectional variance of $h_{i t}$ has the limiting form under convergence.

$$
V_{t^{2}} \sim A / L(t)^{2} t^{2 a} \text { as } t \rightarrow \infty \text { for some } A>0
$$

The following regression based convergence test can be deduced:

$$
\begin{gathered}
\log \left(V_{1}^{2} / V_{t}^{2}\right)-2 \log L(t)=a+b \log t+u_{t} \\
\text { For } t=[r T],[r T]+1, \ldots, T
\end{gathered}
$$


Where generally $\mathrm{r} \in(0,1)$ and $L(t)$ are functions varying slowly. Sul and Phillips (2007), based on Monte Carlo simulations, suggest utilizing $L(t)=\log t$ and $r=0$. for sample sizes below $T=50$. At last, by means of $\hat{b}=2 a$, a one-sided t-test robust to autocorrelation and heteroskedasticity is applied to test the disparity of the null hypothesis $a \geq 0$.

$$
\text { If } \quad t \hat{b}<-1.65 \text { (significance level } 5 \%)
$$

The null hypothesis is negated in that case.

\section{Steps of $\log$ t-test}

The test comprises four steps which can be summed up as follows: First, given the last period in the time-series dimension of the group, units are arranged in descending order. After that, a club convergence is produced by means of the log $\mathrm{t}$ test. Further, this is done by summing up districts one at a time to a set of the two regions of maximum income at the start and operating the $t \log$ test until $t \hat{b}$ is greater than -1.65 . After that, the log t-test is repeated, and one by one, all of the units left behind in the sample to test whether they converge. If not, then to the remaining units, the first three steps are applied. If there are no clubs formed, one may analyse that those units of economy diverge.

\section{Results and Discussion}

In this section, we discuss the findings for club convergence of development index across districts of Pakistan. There are further two sub-sections, the first subsection discusses the empirical results, and the second subsection presents the discussion on empirical results.

\section{Club Convergence of Development Index}

This section discusses the findings for overall convergence and club convergence of the development index. For testing the convergence hypothesis and for identifying the convergence club, we use the technique proposed by Phillips and Sul (2007).

\section{Log t Convergence test}

We begin by testing full convergence in the development index. At first, we run the $\log \mathrm{t}$ regression across 97 districts for the period 2004-2015. The results obtained through this test are summarized in Table 3 . The value of $t$-statistic is less than - 1.65 and is statistically significant at $1 \%$, and hence we reject the null hypothesis of overall convergence among districts. Furthermore, it implies that the convergence hypothesis in the whole sample is rejected. Thus, we need to proceed further for the identification of the clubs. 
Table 3

Phillips Sul log Regression Results

\begin{tabular}{cccc}
\hline Variable & Coeff & SE & T-stat \\
\hline $\log (\mathrm{t})$ & -1.3071 & 0.0510 & -25.6440 \\
\hline
\end{tabular}

Note: convergence test rejects the null hypothesis at the $1 \%$ level

\section{Identification of Clubs}

Given the absence of overall panel convergence, we proceed to determine the formation of convergence clubs. For cub Identification, we apply the Phillips-Sul algorithms of club clustering for a given set of data. Table 4 shows the output obtained for the identification of the clubs. The table shows the formation of 11 Convergence Clubs and one non-converging group.

Table 4

Club Convergence Results

\begin{tabular}{|c|c|c|c|c|}
\hline Clubs & Districts & $\begin{array}{c}\text { No of } \\
\text { districts }\end{array}$ & $\begin{array}{c}b \\
\text { Coefficient } \\
\end{array}$ & $t$ Statistic \\
\hline 1st Club & Lahore, Hyderabad, Karachi & 3 & 0.109 & 0.550 \\
\hline $2^{\text {nd }}$ Club & $\begin{array}{l}\text { Jehlum, Chakwal, Gujranwala, Gujrat, } \\
\text { Sialkot, Sheikhupura, Malakand, } \\
\text { Peshawar, Nowshera, Haripur }\end{array}$ & 10 & 0.316 & 1.433 \\
\hline $3^{\text {rd }}$ Club & Faisalabad, Dadu, Abbottabad, Swabi & 4 & 0.152 & 0.783 \\
\hline $4^{\text {th }}$ Club & $\begin{array}{c}\text { Attock, Sargodha, Khushab, T.T.Singh, } \\
\text { Hafizabad, Mandi Bahuddin, } \\
\text { Narowal, Kasur, Okara, Multan, } \\
\text { Larkana, Lower Dir, Chitral, } \\
\text { Charsada, Kohat, Karak, Mansehra, } \\
\text { Mardan, Quetta. }\end{array}$ & 19 & 0.458 & 2.224 \\
\hline $5^{\text {th }}$ Club & $\begin{array}{l}\text { Sahiwal, Khanewal, Lodhran, Layyah, } \\
\text { Sukkur, NowsheroFeroze, Swat, } \\
\text { Bonair, Hangu, LakkiMarwat, Pashin, } \\
\text { Sibbi, Gwadar. }\end{array}$ & 13 & 0.390 & 1.869 \\
\hline $6^{\text {th }}$ Club & $\begin{array}{l}\text { Mianwali, Jhang, Vehari, Pakpatten, } \\
\text { Muzaffar Garh, Bahawalnager, } \\
\text { Khairpur, Shaheed Benazirabad, } \\
\text { Sanghar, Upper Dir, Batagram, Bannu, } \\
\text { Kalat, Mastung, Kharan, Zhob, } \\
\text { QillaSaifulla. }\end{array}$ & 17 & 0.215 & 1.052 \\
\hline $7^{\text {th }}$ Club & $\begin{array}{c}\text { Bhakhar, Bahawalpur, Rahim Yar } \\
\text { Khan, Ghotki, Shikarpur, Mir Pur } \\
\text { Khas, Shangla, D.I.Khan, Tank, Ziarat. }\end{array}$ & 10 & 0.560 & 2.621 \\
\hline $8^{\text {th }}$ Club & $\begin{array}{l}\text { D.G.khan, Jaccobabad, Khuzdar, } \\
\text { Awaran, Lasbilla, Loralai. }\end{array}$ & 6 & 0.305 & 1.382 \\
\hline $9^{\text {th }}$ Club & $\begin{array}{c}\text { Thatta, Qilla Abdullah, Musa Khel, } \\
\text { Nasirabad, Jafarabad, JhalMagsi, } \\
\text { Bolan }\end{array}$ & 7 & 0.505 & 1.984 \\
\hline
\end{tabular}




\begin{tabular}{ccccc}
\hline $10^{\text {th }}$ Club & Tharparkar, Barkhan. & 2 & 1.493 & 2.565 \\
\hline $11^{\text {th }}$ Club & Kohistan, Chaghi. & 2 & -0.946 & -0.389 \\
\hline $12^{\text {th }}$ Group & $\begin{array}{c}\text { Islamabad, Rawalpindi, Rajanpur, } \\
\text { Badin }\end{array}$ & 4 & -1.418 & -24.736 \\
\hline
\end{tabular}

Note: Results display 11 clubs from row 1 to row 11 and one no-convergent club in row 12

Results from Table 2 clearly show that the development index across 97 districts converged initially to eleven clubs as t-statistics are significantly larger than - 1.65. Four districts, including Islamabad, Rawalpindi, Rajanpur and Badin belong to the non-converging group.

\section{Club Merging Tests (Convergence between the Clubs)}

The convergence algorithm may lead to overestimation of the true number of clubs, as noted by Phillips and Sul (2009). We evaluate merging adjacent clubs into larger clubs by applying club merging tests to tackle this potential issue. We proceed with the analysis by testing for convergence between clubs. Phillips and Sul (2009) proposed log t-test for adjacent clubs after club clustering to merge two or more clubs into new clubs. The logt-test is performed on all the pairs of clubs, and if the convergence hypothesis is satisfied jointly, they can be merged to form a new club. The results are presented in Table 5.

Table 5

Club Merging Test Results

\begin{tabular}{ccccc}
\hline S. No & Merging Clubs & Coefficient & SE & T-stat \\
\hline 1 & Club 1 + Club 2 & -0.3178 & 0.1318 & -2.4105 \\
\hline 2 & Club 2 + Club 3 & -0.0488 & 0.1643 & -0.2974 \\
\hline 3 & Club 3 + Club 4 & 0.0705 & 0.1455 & 0.4843 \\
\hline 4 & Club 4 + Club 5 & -0.5858 & 0.0642 & -9.1196 \\
\hline 5 & Club 5+ Club 6 & -0.1081 & 0.1431 & -0.7555 \\
\hline 6 & Club 6 + Club 7 & 0.1840 & 0.1708 & 1.0770 \\
\hline 7 & Club 7 + Club 8 & -0.2338 & 0.1467 & -1.5939 \\
\hline 8 & Club 8+ Club 9 & -0.3479 & 0.1023 & -3.4000 \\
\hline 9 & Club 9 + Club & 0.4909 & 0.2490 & 1.9715 \\
\hline 10 & Club 10 + Club & -1.9346 & 0.0770 & -25.1191 \\
\hline 11 & Club 11 + G 12 & -1.4634 & 0.0531 & -27.5587 \\
\hline
\end{tabular}

Notes: The G symbol represents the non-converging group

\section{Final Clubs Classification}

The above club merging results revealed that there is evidence of convergence between four groups. The $2^{\text {nd }}$ and $3^{\text {rd }}$ clubs merge to form a club of 19 districts, while the $5^{\text {th }}$ and $6^{\text {th }}$ clubs merge to form a club of 30 districts. The $7^{\text {th }}$ and $8^{\text {th }}$ merge to form a club of 16 districts, while the $9^{\text {th }}$ and $10^{\text {th }}$ clubs combine to form a 
club of 9 districts. After convergence between four groups, the final club classification display shows seven convergence clubs and one divergent group. The results are depicted in Table 6.

The final club classification revealed seven convergence clubs and one nonconverging group. Lahore, Hyderabad and Karachi represent the first club. The second is integrating fourteen districts from Punjab and KPK, including Jhelum, Chakwal, Faisalabad, Gujranwala, Gujrat, Sialkot, and Sheikhupura, Dadu, Malakand, Peshawar, Nowshera, Abbottabad, Haripur and Swabi. The third club comprises Attock, Sargodha, Khushab, T.T.Singh, Hafizabad, Mandi Bahuddin, Narowal, Kasur, Okara, Multan, Larkana, Lower Dir, Chitral, Charsada, Kohat, Karak, Mansehra, Mardan and Quetta. The fourth club encompasses Mianwali, Jhang, Vehari, Sahiwal, Khanewal, Pakpatten, Lodhran, Layyah, Muzaffar Garh, Bahawalnager, Khairpur, Sukkur, Shaheed Benazirabad, NowsheroFeroze, Sanghar, Swat, Upper Dir, Bonair, Hangu, Batagram, Bannu, LakkiMarwat, Pashin, Sibbi, Kalat, Mastung, Kharan, Gwadar, Zhob and Qilla Saifullah. The fifth club consists of Bhakhar, D.G.khan, Bahawalpur, Rahim Yar Khan, Ghotki, Jaccobabad, Shikarpur, Mir Pur Khas, Shangla, D.I.Khan, Tank, Ziarat, Khuzdar, Awaran, Lasbilla and Loralai. The sixth club consists of Thatta, Tharparkar, Qilla Abdullah, Barkhan, Musa Khel, Nasirabad, Jafarabad, JhalMagsi and Bolan. The seventh group contains Kohistan, Chaghi. The last group comprising non-converging districts contains Islamabad, Rawalpindi, Rajanpur, and Badin

Table 6

Final Clubs Classification

\begin{tabular}{|c|c|c|c|c|}
\hline S. No & Final Club & $\begin{array}{c}\text { No of } \\
\text { districts }\end{array}$ & $\begin{array}{c}b \\
\text { Coefficient }\end{array}$ & $t$ Statistic \\
\hline Club 1 & Lahore, Hyderabad, Karachi & 3 & 0.109 & 0.550 \\
\hline Club 2 & $\begin{array}{l}\text { Jehlum, Chakwal, Faisalabad, } \\
\text { Gujranwala, Gujrat, Sialkot, } \\
\text { Sheikhupura, Dadu, Malakand, } \\
\text { Peshawar, Nowshera, } \\
\text { Abbottabad, Haripur, Swabi. }\end{array}$ & 14 & -0.049 & -0.297 \\
\hline Club 3 & $\begin{array}{l}\text { Attock, Sargodha, Khushab, } \\
\text { T.T.Singh, Hafizabad, Mandi } \\
\text { Bahuddin, Narowal, Kasur, } \\
\text { Okara, Multan, Larkana, Lower } \\
\text { Dir, Chitral, Charsada, Kohat, } \\
\text { Karak, Mansehra, Mardan, } \\
\text { Quetta }\end{array}$ & 19 & 0.458 & 2.224 \\
\hline Club 4 & $\begin{array}{l}\text { Mianwali, Jhang, Vehari, } \\
\text { Sahiwal, Khanewal, Pakpatten, } \\
\text { Lodhran, Layyah, Muzaffar } \\
\text { Garh, Bahawalnager, Khairpur, } \\
\text { Sukkur, Shaheed Benazirabad, }\end{array}$ & 30 & -0.108 & -0.756 \\
\hline
\end{tabular}




\begin{tabular}{|c|c|c|c|c|}
\hline & $\begin{array}{c}\text { NowsheroFeroze, Sanghar, Swat, } \\
\text { Upper Dir, Bonair, Hangu, } \\
\text { Batagram, Bannu, LakkiMarwat, } \\
\text { Pashin, Sibbi, Kalat, Mastung, } \\
\text { Kharan, Gwadar, Zhob, Qilla } \\
\text { Saifullah }\end{array}$ & & & \\
\hline Club 5 & $\begin{array}{c}\text { Bhakhar, D.G.khan, Bahawalpur, } \\
\text { Rahim Yar Khan, Ghotki, } \\
\text { Jaccobabad, Shikarpur, Mir Pur } \\
\text { Khas, Shangla, D.I.Kha, Tank, } \\
\text { Ziarat, Khuzdar, Awaran, } \\
\text { Lasbilla, Loralai }\end{array}$ & 16 & -0.234 & -1.594 \\
\hline Club 6 & $\begin{array}{c}\text { Thatta, Tharparkar, Qilla } \\
\text { Abdullah, Barkhan, Musa Khel, } \\
\text { Nasirabad, Jafarabad, JhalMagsi, } \\
\text { Bolan }\end{array}$ & 9 & 0.491 & 1.971 \\
\hline Club 7 & Kohistan, Chaghi & 2 & -0.946 & -0.389 \\
\hline Group 8 & $\begin{array}{l}\text { Islamabad, Rawalpindi, } \\
\text { Rajanpur, Badin }\end{array}$ & 4 & -1.418 & -24.736 \\
\hline
\end{tabular}

Note: Results display 7 clubs from row 1 to row 7 and one no-convergent club in row8.

The club mentioned above results clearly indicates that there is no convergence among districts of Pakistan, as the districts are classified into 7 different convergence clubs and one diverging group. The districts with the same development levels are classified within the same group, while the districts with the highest and lowest development don't merge with any club and are classified as non-converging groups. The final club classification clearly displays that the first three clubs contain 18 districts of Punjab, 13 districts of KP and 4 districts of Sindh. In contrast, Quetta is the only district from Balochistan grouped in the first three convergence clubs. The $4^{\text {th }}$ and $5^{\text {th }}$ clubs encompass 14 districts of Punjab, 10 districts of KP, 9 districts of Sindh and 13 districts of Balochistan. The last two clubs contain 8 districts from Balochistan, 2 districts of Sindh, and one district from KP. The $8^{\text {th }}$ nonconverging group includes the two most developed districts of Punjab, namely, Islamabad and Rawalpindi. It also has the two least developed districts of Punjab and Sindh, respectively, i.e., Rajanpur and Badin.

\section{Conclusion}

This study is inspired by the failure of the neo-classical model in presenting a viable explanation of steady-state growth. It is for that reason that various new types of models were devised, such as the theories of endogenous growth (Romer, 1986; Lucas, 1988; Aghionn and Howit, 1998), the institutional theory (Lundvall, 1992; Nelson, 1993) and the new economic geography (Krugman, 1991; Venables, 1999). These models tend to agree with the fundamental statement of Myrdal (1957) that growth is a growing spatial practice resulting in greater disparities. Another growth 
theory, however, shows that economies that are rather similar in their structural characteristics (e.g., production technology, preferences, government policies, etc.) may converge to different steady-state equilibria if they differ in terms of initial conditions (Azariadis \& Drazen, 1990; Barro \& Sala-i-Martin, 1992; Chatterji, 1992; David, 1994; Durlauf \& Johnson, 1995; Quah, 1996; Azariadis, 1996; Galor, 1996). Hence, within a group of similar economies, a common balanced growth path can only be expected if their initial conditions are also the same. So, economies that approach the same steady-state equilibrium form a convergence club (Galor, 1996). Chatterji (1992) describes that a convergence club implies various regions that are forced in the long run to a level of steady state with the same income per capita.

The paper analyses the presence of club convergence across districts of Pakistan over the period 2014-2015. Instead of using a traditional measure like the per capita GDP as a basis for studying the club convergence hypothesis, the paper explores broader aspects of development. For this purpose, we use the augmented development index. The index is composed of three sub-indices of education, health and Household living standard. Each of them is based on five indicators. The indicators are aggregated through weights obtained from the Principal Component Analysis (PCA), and the Phillips and Sul (2007) technique is employed to determine the number of convergence clubs. The results indicate that instead of overall convergence, we find club convergence for human development across districts of Pakistan. The findings display that there are seven convergence clubs and one nonconvergent group. The existence of seven convergence clubs supports the view that human development is not uniformly distributed across districts of Pakistan. Thus, there is a need to design policies that could reduce spatial disparities in human development across them. 


\section{Reference}

Afzal, U. (2012). Human Capital Convergence: Evidence from the Punjab. The Lahore Journal of Economics, 17(1), 45.

Ahmed, S. (2011). Essays on Spatial Inequalities in Income and Education: Econometric Evidence from Pakistan (Doctoral dissertation, University of Trento).

Alexiadis, S., \& Tomkins, J. (2004). Convergence clubs in the regions of Greece. Applied Economics Letters, 11(6), 387-391.

Andrade, E., Laurini, M., Madalozzo, R., \& Pereira, P. L. V. (2004). Convergence clubs among Brazilian municipalities. Economics Letters, 83(2), 179-184.

Artelaris, P., Kallioras, D., \& Petrakos, G. (2010). Regional inequalities and convergence clubsin the European Union new member-states. Eastern Journal of European Studies, 1(1), 113.

Badinger, H., Müller, W., \&Tondl, G. (2004). Regional convergence in the European Union, 1985-1999: A spatial dynamic panel analysis. Regional Studies, 38(3), 241253.

Bandyopadhyay, S. (2012). Convergence clubs in incomes across Indian states: Is there evidence of a neighbours'effect?.Economics Letters, 116(3), 565-570.

Bartkowska, M., \&Riedl, A. (2012). Regional convergence clubs in Europe: Identification and conditioning factors. Economic Modelling, 29(1), 22-31.

Basel, S., Gopakumar, K. U., \& Rao, R. P. (2020). Testing club convergence of economies by using a broad-based development index. GeoJournal, 1-15.

Beylunioğlu, F. C., Yazgan, M. E., \&Stengos, T. (2018). Detecting Convergence Clubs. Macroeconomic Dynamics, 1-41.

Brida, J. G., Garrido, N., \&Mureddu, F. (2014). Italian economic dualism and convergence clubs at regional level. Quality $\mathcal{E}$ Quantity, 48(1), 439-456.

Canova, F. (2004). Testing for convergence clubs in income per capita: a predictive density approach. International Economic Review, 45(1), 49-77.

Carlino, G. A., \& Mills, L. O. (1993). Are US regional incomes converging? A time series analysis. Journal of monetary economics, 32(2), 335-346.

Chatterji, M., \& Dewhurst, J. L. (1996). Convergence clubs and relative economic performance in Great Britain: 1977-1991. Regional Studies, 30(1), 31-39. 
Dall'Erba, S., \& Le Gallo, J. (2008). Regional convergence and the impact of European structural funds over 1989-1999: A spatial econometric analysis. Papers in Regional Science, 87(2), 219-244.

De Siano, R., \&D'Uva, M. (2006). Club convergence in European regions. Applied Economics Letters, 13(9), 569-574.

Du, K. (2017). Econometric convergence test and club clustering using Stata. The Stata Journal, 17(4), 882-900.

Elmslie, B. T. (1995). Retrospectives: the convergence debate between David Hume and Josiah Tucker. Journal of Economic Perspectives, 9(4), 207-216.

Evans, P., \& Kim, J. U. (2005). Estimating convergence for Asian economies using dynamic random variable models. Economics Letters, 86(2), 159-166.

Evans, P., \& Kim, J. U. (2011). Stochastic convergence of the catch-up rate and multiple structural breaks in Asian countries. Economics Letters, 111(3), 260-263.

Fingleton, B. (2000). Convergence: international comparisons based on a simultaneous equation model with regional effects. International Review of Applied Economics, 14(3), 285-305.

Gajwani, K., Kanbur, R., \& Zhang, X. (2006, January). Patterns of spatial convergence and divergence in India and China. In Annual Bank Conference on Development Economics ( $A B C D E)$, St. Petersburg.

Ghosh, M., Ghoshray, A., \&Malki, I. (2013). Regional divergence and club convergence in India. Economic Modelling, 30, 733-742.

Hoshino, M. (2014). Convergence clubs in china: a comparative analysis of east asia and emerging nations. International Journal of Economics and Business Modeling, 5(1), 227.

Howitt, P., \& Mayer-Foulkes, D. (2002). R\&D, implementation and stagnation: ASchumpeterian theory of convergence clubs (No. w9104). National Bureau of Economic Research.

Kaukab, M. E., \&Surwandono, S. (2021). Convergence of Human Development Index: casestudy of foreign direct investment in ASEAN. Business: Theory and Practice, 22(1), 1217.

Konya, L., \&Guisan, M. C. (2008). What does the human development index tell us about convergence? Applied Econometrics and International Development, 8(1).

Kosfeld, R., \&Lauridsen, J. (2004). Dynamic spatial modelling of regional convergence processes. Empirical Economics, 29(4), 705-722. 
Lau, C. K. M. (2010). New evidence about regional income divergence in China. China Economic Review, 21(2), 293-309.

Lessmann, C., \& Seidel, A. (2017). Regional inequality, convergence, and its determinants-A view from outer space. European Economic Review, 92, 110-132.

Li, F., Li, G., Qin, W., Qin, J., \& Ma, H. (2018). Identifying Economic Growth Convergence Clubs and Their Influencing Factors in China. Sustainability, 10(8), 2588.

Mahapatra, D., Sahoo, D., \&Mahanti, M. (2019). Growth and Inequality at the subregional and sub-sectoral level: Case of Service sector of Odisha, India. Revista de Estudios Regionales, (115), 63-94.

Mcguinness, S., \& Sheehan, M. (1998). Regional convergence in the UK, 1970-1995. Applied economics letters, 5(10), 653-658.

Mendoza-Velázquez, A., German-Soto, V., Monfort, M., \&Ordóñez, J. (2020). Clubconvergence and inter-regional inequality in Mexico, 1940-2015. Applied Economics, 52(6), 598-608.

Mikulić, D., Lovrinčević, Ž.,\&Nagyszombaty, A. G. (2013). Regional convergence in the European Union, new member states and Croatia. South East European Journal of Economics and Business, 8(1), 9-21.

Mohsin, H. M., \& Gilbert, S. (2010). The relative city price convergence in Pakistan: Empirical evidence from spatial GLS. The Pakistan Development Review, 439-448.

Monfort, P., \&Nicolini, R. (2000). Regional convergence and international integration. Journal of Urban Economics, 48(2), 286-306.

Paas, T., Kuusk, A., Schlitte, F., \&Võrk, A. (2007). Econometric analysis of income convergence in selected EU countries and their NUTS 3 level regions. The University of Tartu Faculty of Economics and Business Administration Working Paper, (60-2007).

Pfaffermayr, M. (2012). Spatial convergence of regions revisited: a spatial maximum likelihood panel approach. Journal of Regional Science, 52(5), 857-873.

Quah, D. T. (1996). Twin peaks: growth and convergence in models of distribution dynamics. The economic journal, 106(437), 1045-1055.

Quah, D. T. (1997). Empirics for growth and distribution: stratification, polarization, and convergence clubs. Journal of economic growth, 2(1), 27-59.

Quintana-Romero, L., Prudencio-Vázquez, J. A., \&Páez, C. S. (2016). Inequality and spatial convergence in the Mexico city metropolitan area, 1989-2010. Journal of Reviews on Global Economics, 5, 69-83. 
Rassekh, F. (1998). The convergence hypothesis: History, theory, and evidence. Open economies review, 9(1), 85-105.

Rey, S. J., \&Montouri, B. D. (1999). US regional income convergence: a spatial econometric perspective. Regional studies, 33(2), 143-156.

Roy, H. (2009). Convergence of human development across Indian states. Available at SSRN 1456755.

Sandilah, M. N., \& Yasin, H. M. (2011). Economic growth and regional convergence: the case of Pakistan. The Pakistan Development Review, 333-353.

Sichera, R., \& Pizzuto, P. (2019). ConvergenceClubs: A package for performing the phillips and sul's club convergence clustering procedure. $R$ J, 11, 142-151.

Simionescu, M. (2015). About regional convergence clubs in the European Union. Zbornik radovaEkonomskogfakulteta u Rijeci: časopis za ekonomskuteorijuipraksu, 33(1), 67-80.

Su, J. J. (2003). Convergence clubs among 15 OECD countries. Applied Economics Letters,10(2), 113-118.

Tian, X., Zhang, X., Zhou, Y., \& Yu, X. (2016). Regional income inequality in China revisited: A perspective from club convergence. Economic Modelling, 56, 50-58.

Von Lyncker, K., \&Thoennessen, R. (2017). Regional club convergence in the EU: evidence from a panel data analysis. Empirical Economics, 52(2), 525-553. 